\title{
Expression of Epstein-Barr virus encoded nuclear antigen 1 in benign and malignant tissues harbouring EBV
}

Department of Pathology, Free University Hospital, Amsterdam, The Netherlands

J J Oudejans

D F Dukers

N M Jiwa

A J C van den Brule

$P C$ de Bruin

A Horstman

W Vos

C J L M Meijer

Institut für

Medizinische

Mikrobiologie und

Hygiene, Abteilung

Virologie,

Universitätskliniken

des Saarlandes,

Homburg, Germany

F A Grässer

Department of

Pathology, University

Hospital, Utrecht, The

Netherlands

$\mathrm{J}$ van Gorp

Organon Teknika,

Boxtel, The

Netherlands

J M Middeldorp

Correspondence to:

Dr J J Oudejans,

Department of Pathology,

Free University Hospital,

De Boelelaan 1117,

1081 HV Amsterdam,

The Netherlands.

Accepted for publication 27 June 1996

J J Oudejans, D F Dukers, N M Jiwa, A J C van den Brule, F A Grässer, P C de Bruin, A Horstman, W Vos, J van Gorp, J M Middeldorp, C J L M Meijer

\begin{abstract}
Aims-To determine levels of expression of Epstein-Barr virus (EBV) nuclear antigen 1 (EBNA1) in benign and malignant tissues harbouring $\mathrm{EBV}$ in relation to EBNA1 promoter usage.

Methods-Expression of EBNA1 was investigated by means of immunohistochemistry using a mixture of two EBNA1 specific monoclonal antibodies, $1 \mathrm{H} 4-1$ and 2B4-1. The presence of EBV was detected by EBER1/2 RNA in situ hybridisation. Detection of promoter specific EBNA1 transcripts was by RT-PCR analysis.
\end{abstract}

Results-EBNA1 positive cells were detected in all $20 \mathrm{EBV}$ associated $B$ cell lymphomas, 18 of which had arisen in immunocompromised patients; in eight of nine EBV associated $T$ cell lymphomas; in 11 of $27 \mathrm{EBV}$ positive cases of Hodgkin's disease; and in reactive lymphoid tissue harbouring EBV, including four cases of infectious mononucleosis. A diffuse EBNA1 staining pattern was observed in most of the EBV associated $B$ cell lymphomas and was comparable with the EBER1/2 staining pattern. In the $T$ cell lymphomas the number of EBNA1 positive cells was usually considerably less than the number of EBER1/2 positive ones. RT-PCR analysis revealed that in tumours with restricted EBNA1 expression-that is, $T$ cell lymphomas and Hodgkin's disease lesions, EBNA1 transcripts were usually generated only by the F/Q promoter, whereas in B cell lymphomas EBNA1 transcripts were usually generated by both the $C / W$ and $F / Q$ promoters.

Conclusions-EBNA1 is expressed in all types of tissue harbouring EBV, but the level of expression varies greatly. This may be the result of differential promoter usage.

( Clin Pathol 1996;49:897-902)

Keywords: Epstein-Barr virus, EBNA1, lymphoma.

Epstein-Barr virus (EBV) is the aetiological agent in infectious mononucleosis and has been implicated in the pathogenesis of a growing number of malignancies. Classically, EBV is associated with African Burkitt's lymphoma, ${ }^{1}$ with nasopharyngeal carcinomas ${ }^{2}$ and $\mathrm{B}$ cell lymphomas arising in immunosuppressed patients. ${ }^{34}$ More recently, using a highly sensitive RNA in situ hybridisation assay, ${ }^{5}$ EBV has been detected in the neoplastic cells of a substantial number of cases of Hodgkin's disease $^{6}$ and in certain types of $\mathrm{T}$ cell lymphomas, especially those localised to the nose, lungs and gastrointestinal tract. $^{7-9} \mathrm{~B}$ cell lymphomas arising in patients without overt immune deficiency are sporadically associated with EBV. ${ }^{10} 11$

In studying EBV latent gene expression in lymphomas, EBV nuclear antigen 2 (EBNA2) and latent membrane protein 1 (LMP-1) have been of particular interest, because these are essential for the transforming effect of EBV. ${ }^{12}{ }^{13}$ An aetiological role for EBV in many EBV associated malignancies may be mediated by LMP-1. ${ }^{14-17}$ By contrast, the pathogenic role of EBNA2 in vivo seems to be restricted, as expression of EBNA2 has been detected only in B cell lymphomas arising in immunocompromised patients. ${ }^{318-20}$

Recently, several reports have indicated that EBNA1 is not only involved in viral plasmid DNA replication and maintenance of viral episomes in the cell, ${ }^{12}$ but may also play a more active role in the pathogenesis of lymphomas. ${ }^{2122}$ Srinivas and Sixbey ${ }^{23}$ showed that expression of EBNA1 induces expression of $\mathrm{V}(\mathrm{D}) \mathrm{J}$ recombinase activating genes $\mathrm{RAGl} / 2$, whose aberrant activity has been implicated in chromosomal translocations in haematological neoplasms.

Regulation of EBNA1 transcription is complex. In EBV transformed lymphoblastoid cell lines and in post-transplant B cell lymphomas, EBNA1 and other EBNA mRNAs are derived from highly spliced transcripts that are generated by one of two promoters located on the Bam HI fragments $\mathrm{C}$ and $\mathrm{W}$ and referred to as the C/W promoter. ${ }^{12}{ }^{29}$ Selective expression of EBNA1 without expression of the other EBNAs in other EBV associated malignancies (including Burkitt's lymphoma, ${ }^{24}$ Hodgkin's disease, ${ }^{16} \mathrm{~T}$ cell lymphomas, ${ }^{17}$ and nasopharyngeal carcinomas ${ }^{15}$ ) results from activation of a separate EBNA1 promoter, probably located on the Bam HI Q fragment and referred to as the $\mathrm{Q}$ promoter. ${ }^{25}$ In lytic EBV infection EBNA1 transcripts are generated by the F promoter located just upstream from the $Q$ promoter. $^{2526}$ 
It is possible that the putative oncogenic effect of EBNA1 is related to its level of expression. Recently, EBNA1 specific antibodies became available, enabling the detection of EBNA1 on conventional paraffin wax embedded tissue sections. ${ }^{27}$ Using these antibodies, we investigated whether there are differences in the level of expression of EBNA1 in benign and malignant lesions harbouring EBV. Reverse transcription polymerase chain reaction (RTPCR) analysis was also carried out to investigate whether such differences could be explained by differential usage of the EBNA1 promoters.

\section{Methods}

Paraffin wax sections from 18 lymphomas arising in immunocompromised patients, 12 posttransplant lymphomas and six AIDS related B cell lymphomas, and two B cell lymphomas, nine $T$ cell lymphomas and 27 cases of Hodgkins's disease, all arising in patients without overt immune deficiency, and four cases of infectious mononucleosis were studied. In all cases the presence of EBV was demonstrated by EBER1/2 RNA in situ hybridisation, as described previously. ${ }^{28}$ Lymphomas with more than $70 \%$ EBER1/2 positive neoplastic cells were considered to be EBV associated. ${ }^{729}$ One hyperplastic tonsil and one reactive lymph node harbouring sporadic EBER1/2 positive small lymphocytes were also analysed.

Non-Hodgkin's lymphomas were classified according to the updated Kiel classification ${ }^{30}$ and the REAL classification, ${ }^{31}$ with the exception of some of the post-transplant lymphomas and AIDS related lymphomas, which are difficult to classify according to the Kiel classification because of their notable polymorphism. ${ }^{4233}$ Cases of Hodgkin's disease were classified according to the Rye classification. ${ }^{34}$ If snap frozen material was available, RNA was isolated for RT-PCR.

The EBV positive cell lines JY (EBV transformed lymphoblastoid cell line) and RAJI (a Burkitt's lymphoma derived cell line) served as positive controls for both immunohistochemistry and RT-PCR. Negative controls consisted of two EBV negative cell lines (RAMOS, BJAB) and of several cases of EBV negative Hodgkin's disease and non-Hodgkin's lymphoma.

\section{IMMUNOHISTOCHEMISTRY}

The specificities of rat monoclonal antibodies 1H4-1 and 2B4-1 directed against EBNA1 have been described elsewhere. ${ }^{27}$ Immunohistochemistry was performed on paraffin wax sections, fixed either in buffered formaldehyde or sublimate formaldehyde. Briefly, tissue sections were deparaffinised in xylene and incubated with hydrogen peroxidase to block endogenous peroxidase. After antigen retrieval in $0.1 \mathrm{~mol} / 1$ citrate buffer, $\mathrm{pH} 6.0$, for $10 \mathrm{~min}$ utes in a pressure cooker, tissue sections were washed, pre-incubated with normal serum and incubated with a mixture of $1 \mathrm{H} 4-1$ (rat IgG2a) and 2B4-1 (rat IgG1) for one hour at a dilution of 1 in 200. Subsequently, sections were incubated with biotinylated goat anti-rat followed by incubation with an $\mathrm{ABC}$ horse radish peroxidase (HRP) complex (Dako, Glostrup, Denmark). Amplification of signal intensity was obtained by deposition of biotinylated tyramine (BT) on the bound ABC-HRP complex through the enzymatic reaction between tyramine and HRP. ${ }^{35}$ This was followed by a second incubation period with ABC-HRP. Diaminobenzidine (DAB) was used as the chromogen. Inclusion of this amplification step enhanced the staining intensities and revealed greater numbers of EBNA1 positive cells compared with the routine $A B C$ method lacking this step.

In $T$ and $B$ cell lymphomas the number of EBER1/2 and EBNA1 positive cells was estimated visually, as described by Weiss et al $^{36}$ with slight modifications. ${ }^{8}$ Using a $\times 12.5$ ocular and a $\times 25$ objective for screening the tissue slides, lymphomas were divided into diffuse (over 100 cells per medium power field (mpf)), clustered (between 25 and 100 cells per mpf), scattered (less than 25 cells per mpf) or single cell (less than one cell per mpf) positive cases. Negative controls included isotype matched rat monoclonal antibodies.

RT-PCR

RT-PCR analysis was performed using intron flanking primers. Two primer combinations were used to detect EBNA1 specific transcripts. One set was used to detect $\mathrm{Y} 3 / \mathrm{U} / \mathrm{K}$ spliced transcripts, probably generated by the $\mathrm{C} / \mathrm{W}$ promoter, and the other to detect $\mathrm{Q} / \mathrm{U} / \mathrm{K}$ spliced transcripts generated by the $F / Q$ promoter. Cases were excluded if the mRNA seemed to be of poor quality, as determined by RT-PCR using primers specific for $\mathrm{U}^{1} \mathrm{~A}^{37}$ and for rightward reading EBV transcripts from the Bam HI A region (BARF0), which is present in all tissue harbouring $E B V .^{38}$ The primer sequences and oligo probes used for analysis of EBNA1 and BARF0 were as reported previously. ${ }^{1516}$ The conditions used for RNA isolation, RT-PCR analysis and Southern blot hybridisation have been described elsewhere. ${ }^{39}$ In all experiments positive and negative controls were included to test the specificity and sensitivity of the RT-PCR conditions.

\section{Results}

EBNA1 EXPRESSION IN B CELL LYMPHOMAS ARISING IN IMMUNOCOMPROMISED PATIENTS

Table 1 summarises the results. All 18 cases were diffuse large $B$ cell proliferations with a diffuse EBER1/2 staining pattern. In all cases EBNA1 positive cells displayed the nuclear, fine granular staining pattern characteristic of EBNA1 reactivity. ${ }^{27}$

A diffuse EBNA1 staining pattern was observed in 14 cases, with strong EBNA1 positivity in most of the neoplastic cells (fig 1A). In three cases clustered EBNA1 positive cells were observed while scattered EBNA1 positive cells were present in another case. The EBER1/2 staining pattern was diffuse in all cases. 
Table 1 Patterns of expression of EBER1/2 and EBNA1 in EBV associated B cell lymphoproliferative disorders

\begin{tabular}{|c|c|c|c|c|c|c|c|c|c|}
\hline \multirow[t]{2}{*}{ Diagnosis } & \multirow{2}{*}{$\begin{array}{l}\text { Number of } \\
\text { cases }\end{array}$} & \multicolumn{3}{|c|}{$E B E R 1 / 2$} & \multicolumn{3}{|c|}{ EBNA1 protein } & \multicolumn{2}{|c|}{$E B N A 1 m R N A$} \\
\hline & & Diffuse & Clustered & Scattered & Diffuse & Clustered & Scattered & $Y 3 / U / K$ & $Q / U / K$ \\
\hline \multicolumn{10}{|l|}{ Immunocompromised patients } \\
\hline Post-transplant lymphomas & 12 & 12 & 0 & 0 & 9 & 2 & 1 & $5 / 5$ & $4 / 5$ \\
\hline AIDS related lymphomas & 6 & 6 & 0 & 0 & 5 & 1 & 0 & ND & ND \\
\hline \multicolumn{10}{|c|}{ Patients without overt immune deficiency } \\
\hline $\mathrm{B}$ cell lymphomas & 2 & 2 & 0 & 0 & 2 & 0 & 0 & $1 / 2^{\star}$ & $1 / 2$ \\
\hline
\end{tabular}

* One case harboured $\mathrm{Y} 3 / \mathrm{U} / \mathrm{K}$ spliced EBNA1 transcripts and the other case Q/U/K spliced EBNA1 specific transcripts.

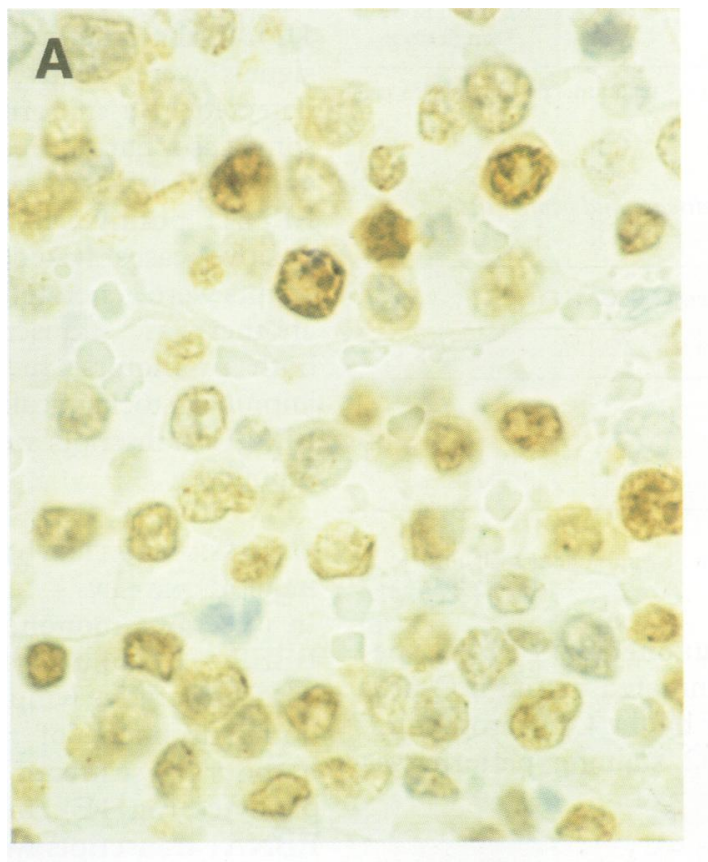

B
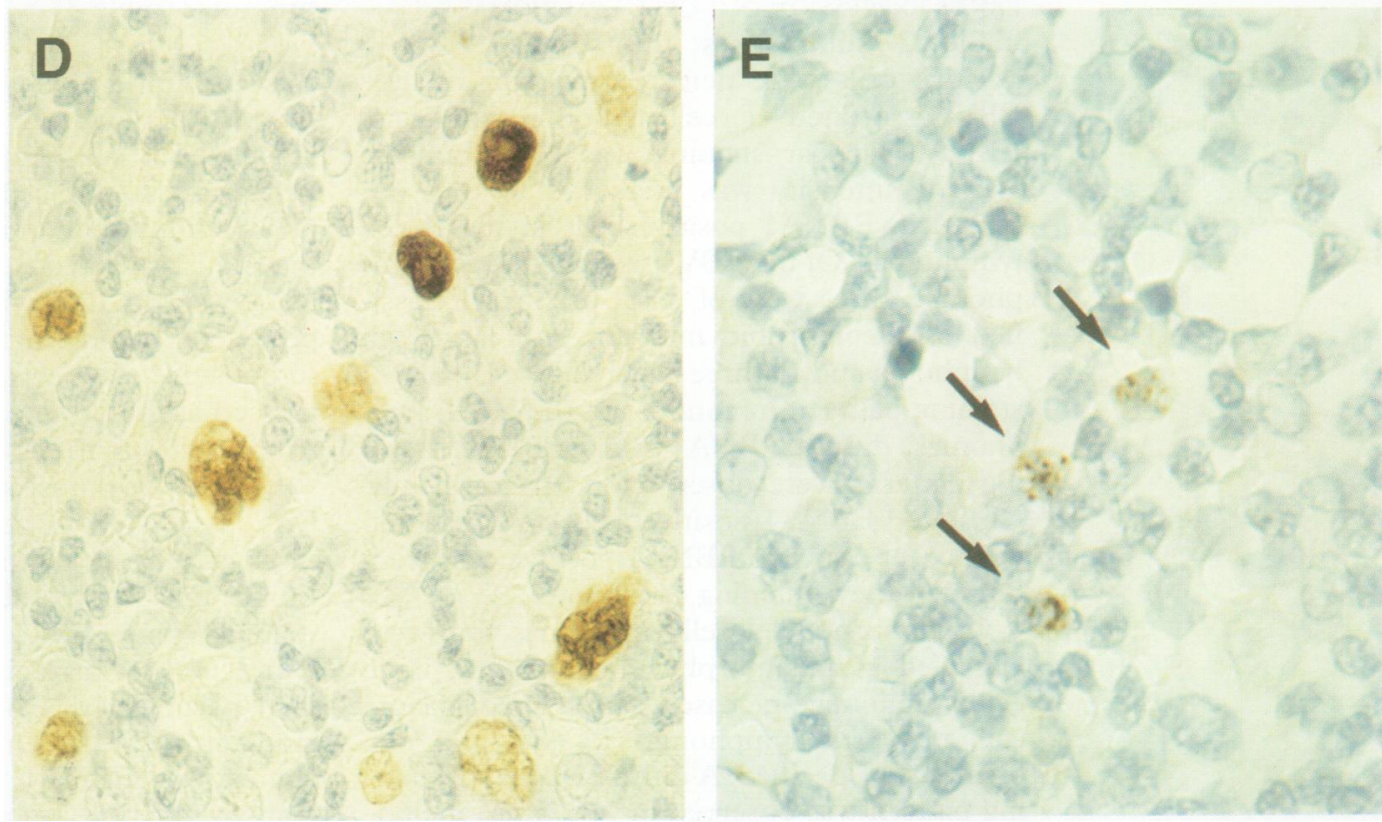

Figure 1 (A) EBNA1 is expressed strongly in neoplastic cell nuclei of patients with $B$ cell lymphoma. (B) EBNA1 expression in a nodal $T$ cell lymphoma. Positive neoplastic cells are indicated by arrowheads. (C) EBER1/2 expression in the same nodal $T$ cell lymphoma. In this case the EBNA1 positive cells are clearly outnumbered by the EBER1/2 positive cells. (D) EBV associated Hodgkin's disease. EBNA1 is expressed in most $H-R S$ cells. (E) Reactive lymph node. Sporadic EBNA1 positive lymphocytes are present in the paracortex (arrows).

RT-PCR analysis revealed the presence of Y3/U/K spliced EBNA1 transcripts, generated by the $\mathrm{C} / \mathrm{W}$ promoter, in all five cases tested. Additional $\mathrm{Q} / \mathrm{U} / \mathrm{K}$ spliced transcripts, generated by the $F / Q$ promoter, were found in four cases.
EBNA1 EXPRESSION IN B CELL LYMPHOMAS IN PATIENTS WITHOUT OVERT IMMUNE DEFICIENCY Both cases were classified as diffuse large B cell lymphoma or diffuse polymorphous centroblastic lymphoma. A diffuse EBNA1 staining pattern was observed in both cases. RT-PCR 
Table 2 Patterns of expression of EBER1/2 and EBNA1 in EBV associated $T$ cell lymphomas

\begin{tabular}{|c|c|c|c|c|c|}
\hline \multirow[t]{2}{*}{ Classification } & \multirow[t]{2}{*}{ EBER1/2 } & \multirow{2}{*}{$\begin{array}{l}\text { EBNA1 } \\
\text { protein }\end{array}$} & \multicolumn{2}{|c|}{$E B N A 1 m R N A$} & \multirow[t]{2}{*}{ Site } \\
\hline & & & $\mathrm{Y} 3 / \mathrm{U} / \mathrm{K}$ & $Q / U / K$ & \\
\hline \multicolumn{6}{|c|}{ Patients without overt immune deficiency } \\
\hline $\mathrm{T}$ cell lymphoma ${ }^{\star}$ & Diffuse & Diffuse & - & + & Nose \\
\hline $\mathrm{T}$ cell lymphoma & Diffuse & Clustered & - & - & Nose \\
\hline $\mathrm{T}$ cell lymphoma & Diffuse & - & - & + & Nose \\
\hline $\mathrm{T}$ cell lymphoma & Diffuse & Clustered & ND & ND & Lymph node \\
\hline $\mathrm{T}$ cell lymphoma & Clustered & Clustered & - & + & Lymph node \\
\hline $\mathrm{T}$ cell lymphoma & Clustered & Scattered & ND & ND & Lymph node \\
\hline $\mathrm{T}$ cell lymphoma & Clustered & Scattered & ND & ND & Lymph node \\
\hline $\mathrm{T}$ cell lymphoma & Clustered & Scattered & $\mathrm{ND}$ & ND & Lymph node \\
\hline LCAL & Diffuse & Diffuse & + & - & Lymph node \\
\hline
\end{tabular}

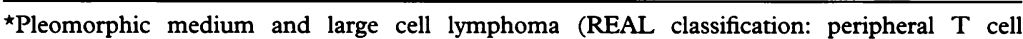
lymphoma, unspecified)

LCAL = large cell anaplastic lymphoma; ND = not determined

Table 3 EBNA1 expression in EBV associated Hodgkin's disease and benign tissues harbouring $E B V$

\begin{tabular}{lllll}
\hline Diagnosis & Number of cases & EBNA1 protein & \multicolumn{2}{l}{$E B N A 1$ mRNA } \\
\cline { 5 - 5 } & & & $Y 3 / U / K$ & Q/U/K \\
\hline Patients without overt immune deficiency & 27 & 11 & $1 / 4^{\star}$ & $4 / 8 \dagger$ \\
Hodgkin's disease & 4 & 4 & ND & ND \\
Infectious mononucleosis & 2 & 2 & $0 / 1$ & $1 / 1$ \\
Reactive lymphoid tissue & 2 & &
\end{tabular}

*One case harboured both EBNA1 transcripts. ${ }^{39}$

†Two of four EBNAl mRNA positive cases were EBNAl negative by immunohistochemistry. $\mathrm{ND}=$ not determined scripts were generated by the $F / Q$ promoter. In the LCAL, however, EBNA1 transcripts were generated by the $\mathrm{C} / \mathrm{W}$ promoter.

EXPRESSION OF EBNAI IN PATIENTS WITH HODGKIN'S DISEASE

The data are summarised in table 3. In 11 of 27 EBV associated cases of Hodgkin's disease, EBNA1 positive staining was observed in the nuclei of the Hodgkin and Reed-Sternberg cells (H-RS cells). In four of these cases, most of the H-RS cells were EBNA1 positive (fig 1D). In the other seven cases EBNA1 positive signals were relatively weak and were only detected in a minority of the H-RS cells. In some cases harbouring EBER1/2 positive small and medium sized cells, these cells were also EBNA1 positive. In one of the four EBNA1 positive cases tested, EBNA1 specific transcripts were generated by the $F / Q$ promoter. In another case, transcripts were generated by both promotors. In two EBER $1 / 2$ positive, immunohistochemically EBNAl negative cases, EBNA1 transcripts were derived from the $F / Q$ promoter.

\section{EXPRESSION OF EBNA1 IN BENIGN TISSUES} HARBOURING EBV

In infectious mononucleosis the EBNA1 and EBER 1/2 staining patterns were very similar. EBNA1 positive lymphocytes were observed in both specimens of reactive lymphoid tissue harbouring scattered EBER $1 / 2$ positive lymphocytes (fig $1 \mathrm{E}$ ). In the hyperplastic tonsil, EBNA1 transcripts were generated by the $F / Q$ promoter (table 3 ).

EBNA1 EXPRESSION IN T CELL LYMPHOMAS

Table 2 summarises the results. EBNA1 positive cells were detected in eight of nine EBV associated $\mathrm{T}$ cell lymphomas. Again, EBNA1 nuclear staining was seen, but the staining intensity was weaker than that observed in EBNA1 positive cells in the $B$ cell lymphomas. Of the EBV associated T cell lymphomas, three were of nasal origin, all classified as pleomorphic medium and large cell lymphoma and all three had a diffuse EBER1/2 staining pattern. In contrast to the B cell lymphomas, diffuse EBNA1 and EBER1/2 staining patterns were observed in one case only. Clustered EBNA1 positive cells were detected in another case. No EBNA1 positive cells were found in the remaining case.

Of the six nodal $\mathrm{T}$ cell lymphomas, four were classified as pleomorphic medium and large cell lymphoma, one case was classified as large cell anaplastic lymphoma (LCAL) and one case was unspecified. A diffuse EBER1/2 staining pattern was observed in two cases, including the LCAL, and a clustered pattern was seen in the remaining four. EBNA1 positive cells were found in all six cases. However, EBER $1 / 2$ positive cells usually outnumbered the EBNA1 positive ones (figs $1 \mathrm{~B}$ and $1 \mathrm{C}$ ). In one $T$ cell lymphoma and in the single LCAL with a clustered EBER1/2 positive staining pattern, the number of EBNA1 positive cells was comparable with the number of EBER1/2 positive ones.

RT-PCR analysis revealed that in three of five $T$ cell lymphomas tested, EBNAl tran-

\section{Discussion}

Expression of EBNA1 was observed in all EBV associated B cell lymphomas, in eight of nine EBV associated $T$ cell lymphomas, in all cases of infectious mononucleosis, and in some of the EBV associated cases of Hodgkin's disease. Moreover, in line with previous findings in peripheral blood lymphocytes of healthy EBV seropositive subjects, ${ }^{4041}$ EBNA1 was expressed at the protein level in latently infected lymphocytes in reactive lymphoid tissues.

EBNA1 was most strongly expressed in the EBV associated $B$ cell lymphomas. In most cases a diffuse staining pattern was found, which was comparable with the EBER1/2 staining pattern. Contrasting results were found in EBV associated $T$ cell lymphomas and particularly EBV associated cases of Hodgkin's disease. One T cell lymphoma did not express EBNA1 and in another six the number of EBNA1 positive cells was considerably smaller than the number of EBER $1 / 2$ positive cells. In agreement with previous findings, ${ }^{27}$ EBNA1 expression could only be detected in some EBV associated cases of Hodgkin's disease and generally only in a minority of H-RS cells. LMP-1, however, is usually expressed strongly in almost all H-RS cells in all EBV positive cases. ${ }^{42}$ Our findings, in contrast with those of Khan and Naase, ${ }^{43}$ suggest that EBNA1 is expressed in at least some cases of EBV associated Hodgkin's disease. 

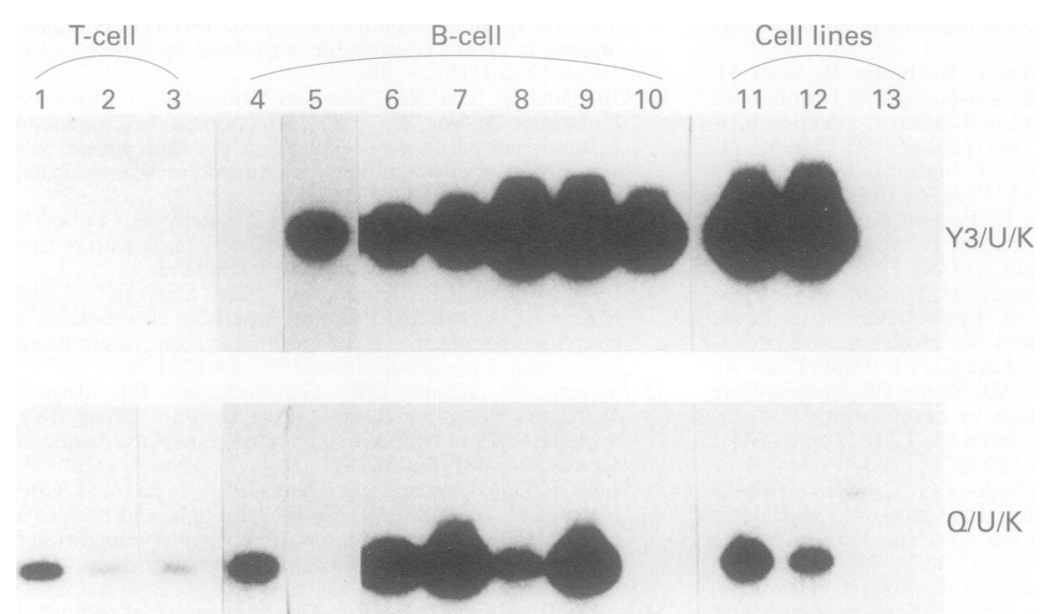

Figure 2 Southern blot of EBNA1 specific RT-PCR products. Upper panel. Strong $Y 3 / U / K$ spliced (derived from the $C / W$ promoter) $E B N A 1$ specific signals were detected in one of two $B$ cell lymphomas arising in patients without overt immune deficiency (lane 5), in all five post-transplant lymphomas (lanes 6-10) and in the FY and RAFI cell lines (lanes 11 and 12, respectively). Lower panel. Relatively faint $Q / U / K$ spliced (probably derived from the $Q$ promoter) $E B N A 1$ specific signals were found in one clustered and two diffuse EBER1/2 positive T cell lymphomas (lanes $1-3$ ). Clear signals were found in one $B$ cell lymphoma arising in a patient without overt immune deficiency (lane 4), in four of five post-transplant lymphomas (lanes 6-9) and in both EBV positive cell lines. In these cases the $Q / U / K$ spliced EBNA1 specific signals were probably generated by the $F$ promoter. ${ }^{25}$ $E B N A 1$ specific transcripts were never detected in the EBV negative BfAB cell line lane 13.)

As EBNA1 is essential for the maintenance of viral episomes in the cell, ${ }^{12}$ the restricted expression of EBNA1 is some cases is probably because EBNA1 was present in concentrations below the detection limit of the antibodies used. This hypothesis is supported by the observation that in several of the cases of $B$ and $\mathrm{T}$ cell lymphomas studied here considerably fewer EBNA1 positive cells were identified when the BT signal amplification step was omitted. In addition, we could detect EBNA1 specific transcripts by RT-PCR analysis in two cases of Hodgkin's disease and in one $\mathrm{T}$ cell lymphoma which were both EBNA1 negative by immunohistochemistry. It is also possible that the epitopes recognised by the $1 \mathrm{H} 4-1$ and 2B4-1 antibodies were blocked, perhaps by other DNA binding proteins.

When EBNA1 staining results were compared with EBNAl promoter usage, it seemed that in cases with strong EBNA1 positive staining in the majority of EBER $1 / 2$ positive cells (most B cell lymphomas), transcripts were derived from both promoters. In cases with weak EBNA1 positive staining in a minority of EBER1/2 positive cells (most cases of Hodgkin's disease and $\mathrm{T}$ cell lymphomas), transcripts were generally derived from the $F / Q$ promoter, which is in agreement with previous reports. ${ }^{16}{ }^{17}$ The primers used in this study cannot discriminate between EBNA1 transcripts derived from the $\mathrm{F}$ and $\mathrm{Q}$ promotors. Recently, however, Schaefer et $a l^{25}$ showed that the $\mathrm{F}$ promoter is activated only during the lytic cycle. Therefore, the $\mathrm{Q} / \mathrm{U} / \mathrm{K}$ spliced EBNA1 transcripts found in cases of Hodgkin's disease and $T$ cell lymphoma are probably generated by the $Q$ promoter, whereas the $Q / U / K$ spliced transcripts present in four of the five posttransplant lymphomas are probably generated by the $F$ promoter or a mixture of $F$ and $Q$ promoters, as in all of these cases expression of the lytic EBV encoded ZEBRA protein was detected in a minority of cells. ${ }^{29}$ These data suggest that $Q$ promoter usage results in lower levels of EBNA1 expression than $\mathrm{C} / \mathrm{W}$ or $\mathrm{F}$ promoter usage. Although a (semi-)quantitative RT-PCR assay was not performed, this hypothesis was supported by the differences in signal intensity. Strong amplification signals were observed for both $\mathrm{C} / \mathrm{W}$ and $\mathrm{F}$ promoter derived EBNA1 transcripts in the $\mathrm{B}$ cell lymphomas, whereas faint bands were found for the $Q$ promoter derived EBNA1 transcripts in the diffuse EBER1/2 positive $T$ cell lymphomas (fig 2 ).

These different levels of EBNA1 expression may have implications for the pathogenic role of EBV in the different types of EBV associated lymphomas. It has been shown previously that activation of cellular oncogenes, such as c-myc, is associated with progression of posttransplant lymphomas and AIDS related lymphomas. ${ }^{3344}$ In EBV associated cases, the possibility of a translocation occurring may be increased considerably as a result of EBNA1 induced expression of RAG $1 / 2 .{ }^{23}$ The relatively strong EBNA1 expression observed in the B cell lymphomas in present study supports the notion that in these lymphomas the occurrence of translocations can be facilitated by EBNA1 induced expression of RAG1/2. In addition, such a mechanism might explain why patients with EBV positive AIDS related lymphoma have a worse prognosis than patients with the EBV negative variant. ${ }^{44}$

In conclusion, consistent with its essential role in maintenance of viral episomes in the host cell, EBNA1 is expressed at the protein level in all types of tissue harbouring EBV, but the level of expression varies greatly. Moreover, our data suggest that these differences are the result of differential EBNA1 promoter usage.

This work was supported by a grant from the Dutch Cancer Society (VU 94-749).

1 Miller G. Epstein-Barr virus, biology, pathogenesis and medical aspects. In: Fields BN, Knipe DM, eds. Virology. New York: Raven Press, 1990:1921-57.

2 Raab-Traub N. Epstein-Barr virus and nasopharyngeal carcinoma. Semin Cancer Biol 1992;3:297-307.

3 Young L, Alfieri C, Hennessy K, Evans H, O'Hara C, Anderson KC, et al. Expression of Epstein-Barr virus transformation associated genes in tissues of patients with EBV lymphoproliferative disease. $N$ Engl F Med 1989;321: 1080-5.

4 Hamilton-Dutoit SJ, Pallesen G, Franzmann MB, Karkov J, Black F, Skinhoj P, et al. AIDS-related lymphoma. Histopathology, immunophenotype and association with Epstein-Barr virus as demonstrated by in-situ nucleic acid hybridisation. Am $\mathcal{F}$ Pathol 1991;138:149-63.

5 Howe JG, Steitz JA. Localization of Epstein-Barr virusencoded small RNAs by in situ hybridization. Proc Natl Acad Sci USA 1984;83:9006-10.

6 Weiss LM, Movahed LA, Warnke RA, Sklar J. Detection of Epstein-Barr viral genomes in Reed Sternberg cells of Hodgkin's disease. N Engl f Med 1989;320:502-6.

7 De Bruin PC, Jiwa NM, van der Valk P, van Heerde P, Meijer CJLM. Detection of Epstein-Barr virus nucleic acid sequences and protein in nodal T-cell lymphomas: Relation between latent membrane protein 1 positivity and clinical between latent membrane protein 1 posid

8 De Bruin PC, Jiwa NM, Oudejans JJ, van der Valk P, van Heerde P, Sabourin J, et al. Presence of Epstein-Barr virus in extranodal T-cell lymphomas: differences in relation to site. Blood 1994;83:1612-18.

9 Korbjuhn P, Anagnostopoulos I, Hummel M, Tremann M, Dallenbach F, Parwaresch MR, et al. Frequent latent Epstein-Barr virus infection of neoplastic $T$ cells and bystander B cells in human immunodeficiency virus negative European peripheral pleomorphic T-cell lymphomas. Blood 1993;82:217-23.

10 Hamilton-Dutoit SJ, Pallesen G. Detection of Epstein-Barr virus small RNAs in routine paraffin sections using 
non-isotopic RNA/RNA in situ hybridization. Histopathology 1994;25:101-11.

11 Hummel M, Anagnostopoulos I, Korbjuhn P, Stein H. Epstein-Barr virus in B-cell non-Hodgkin's lymphomas: Unexpected infection patterns and different infection incidence in low and high-grade types. $\mathcal{F}$ Pathol 1995;175:263-71.

12 Middleton T, Gahn TA, Martin JM, Sugden B. Immortalizing genes of Epstein-Barr virus. Adv Virus Res 1991;40:19-55.

13 Kaye KM, Izumi KM, Kieff E. Epstein-Barr virus latent membrane protein 1 is essential for B-lymphocyte growth transformation. Proc Natl Acad Sci USA 1993;90:9150-4.

14 Herbst H, Dallenbach F, Hummel M, Niedobitek G, Pileri $\mathrm{S}$, Mueller-Lantzsch $\mathrm{N}$, et al. Epstein-Barr virus latent membrane protein expression in Hodgkin and Reedmembrane protein expression in Hodgkin and Reed-

15 Brooks L, Yao QY, Rickinson AB, Young LS. Epstein-Barr virus latent gene transcription in nasopharyngeal carcinoma cells: co-expression of EBNA1, LMP1, and LMP2 transcripts. $\mathcal{F}$ Virol 1992;66:2689-97.

16 Deacon EM, Pallesen G, Nieboditek G, Crocker J, Brooks $\mathrm{L}$, Rickinson $\mathrm{AB}$, et al. Epstein-Barr virus and Hodgkin's disease: transcriptional analysis of virus latency in the malignant cells. $\mathcal{F}$ Exp Med 1993;177:339-49.

17 Chen C, Sadler RH, Walling DM, Su IH, Hsieh H, Raab-Traub N. Epstein-Barr virus (EBV) gene expression in EBV-positive peripheral T-cell lymphomas. $\mathcal{F}$ Virol 1993; 67:6303-8.

18 Rea D, Fourcade C, Leblond V, Rowe M, Joab I, Edelman $L$, et al. Patterns of Epstein-Barr virus latent and replicative gene expression in Epstein-Barr virus B cell lymphoproliferative disorders after organ transplantation. Transplantation 1994;58:317-24

19 Gratama JW, Zutter MM, Minarovits J, Oosterveer MA, Thomas ED, Klein G, et al. Expression of Epstein-Barr virus-encoded growth-transformation-associated proteins in lymphoproliferations of bone-marrow transplant recipients. Int $\mathcal{F}$ Cancer 1991;47:188-92.

20 Thomas JA, Hotchin NA, Allday MJ, Amiot P, Rose M, Jacoub $\mathrm{M}$, et al. Immunohistology of Epstein-Barr virusassociated antigens in B-cell disorders from immunocompromised individuals. Transplantation 1990;49:944-53.

21 Magrath I, Jain V, Bhatia K. Molecular epidemiology of Burkitt's lymphoma. In: Pagano J, Rickinson $\mathrm{AB}$, eds. The Epstein-Barr virus and associated diseases. New York, CSHL Press, 1994:377.

22 Wilson JB, Levine AJ. The oncogenic potential of EpsteinBarr virus nuclear antigen-1 in transgenic mice. Curr Top Microbiol Immunol 1992;182:374-84.

23 Srinivas SK, Sixbey J. Epstein-Barr virus induction of recombinase-activating genes RAG1 and RAG2. $f$ Virol recombinase-activat

24 Sample J, Brooks L, Sample C, Young L, Rowe M, Gregory $\mathrm{C}$, et al. Restricted Epstein-Barr virus protein expression in Burkitt lymphoma is due to a different Epstein-Barr nuclear antigen 1 transcriptional initiation site. Proc Natl Acad Sci USA 1991;88:6343-47.

25 Schaefer BC, Strominger JL, Speck SH. The Epstein-Barr virus BamHI F promoter is an early lytic promoter: Lack of correlation with EBNAl gene transcription in group 1 Burkitt's lymphoma cell lines. $\mathcal{F}$ Virol 1995;69:5039-47.

26 Lear AL, Rowe M, Kurilla MG, Lee S, Henderson S, Kieff $\mathrm{E}$, et al. The Epstein-Barr virus (EBV) nuclear antigen 1
Bam HI F promoter is activated on entry of EBV transformed B-cells into the lytic cycle. $f$ Virol 1992;66; 7461-8.

27 Grässer FA, Murray PG, Kremmer E, Klein K, Remberger K, Feiden W, et al. Monoclonal antibodies directed against the Epstein-Barr virus-encoded nuclear antigen 1 (EBNA1): Immunohistologic detection of EBNA1 in the malignant cells of Hodgkin's disease. Blood 1994;84:3792-8.

28 Jiwa NM, Kanavaros P, De Bruin PC, van der Valk P, Horstman A, Vos W, et al. Presence of Epstein-Barr virus harbouring small and intermediate-sized cells in Hodgkin's disease. Is there a relationship with Reed-Sternberg cells? $\mathcal{f}$ Pathol 1993;170:129-36.

29 Oudejans JJ, Jiwa NM, van den Brule AJC, Grässer FA Horstman A, Vos W, et al. Detection of heterogeneous Epstein-Barr virus gene expression patterns within individual post-transplantation lymphoproliferative disorders. Am f Pathol 1995;147:923-33.

30 Stansfeld AG, Diebold D, Kapanci Y, Kelenyi G, Lennert K, Mioduszewska $\mathrm{O}$, et al. Updated Kiel classification of nonHodgkin's lymphomas. Lancet 1988;i:292-3.

31 Harris NL, Jaffe ES, Stein H, Banks PM, Chan JKC, Cleary $\mathrm{ML}$, et al. A revised European-American classification of lymphoid neoplasms: A proposal from the international lymphoma study group. Blood 1994;84:1361-92.

32 Frizzera G, Hanto DW, Gajl-Peczalska KJ, Rosa J McKenna R, Sibley R, et al. Polymorphic diffuse B-cell hyperplasias and lymphomas in renal transplant recipients, Cancer Res 1981;41:4262-79.

33 Knowles DM, Cesarman E, Chadburn A, Frizzera G, Chen $\mathrm{J}$, Rose EA, et al. Correlative morphologic and molecular genetic analysis demonstrates three distinct categories of posttransplantation lymphoproliferative disorders. Blood 1995;85:552-65.

34 Lukes RJ, Craver LF, Hall TC, Rappaport H, Ruben P. Report of the nomenclature committee. Cancer Res 1966;26:1310-11.

35 Bobrow MN, Shaughnessy KJ, Litt GJ. Catalyzed reporter deposition, a novel method of signal amplification. II Application to membrane immunoassays. F Immunol Methods 1991;137:103-12.

36 Weiss LM, Jaffe ES, Liu X-F, Chen Y-Y, Shibata D, Medeiros LJ. Detection and localization of Epstein-Barr vira genomes in angioimmunoblastic lymphadenopathy and angioimmunoblastic lymphadenopathy-like lymphoma. Blood 1992;79:1789-95.

37 Bijl J, van Oostveen JW, Krieke M, Rieger E, van der RaaijHelmer L, Walboomers JMM, et al. Expression of HOXC4 $-\mathrm{C} 5$ and $-\mathrm{C} 6$ in human lymphoid cell lines, leukemias and in benign and malignant lymphoid tissue. Blood 1996;87: $1737-45$

38 Brooks LA, Lear AL, Young LS, Rickinson AB. Transcripts from the Epstein-Barr virus BamHI A fragment are detectable in all three forms of virus latency. F Virol 1993;67: 3182-90.

39 Oudejans JJ, van den Brule AJC, Jiwa NM, de Bruin PC Ossenkoppele GJ, van der Valk $P$, et al. BHRF1, the Epstein-Barr virus (EBV) homologue of the bcl-2 (proto-) oncogene is transcribed in EBV associated B-cell lymphomas and in reactive lymphocytes. Blood 1995;86: 1893-902.

40 Chen F, Zou J, di Renzo L, Winberg G, Hu l, Klein E, et al. A subpopulation of normal B cells latently infected with Epstein-Barr virus resembling Burkitt lymphoma cells in expressing EBNA-1 but not EBNA-2 or LMP-1. $\mathcal{f}$ Virol 1995;69:3752-8.

41 Tierney, RJ, Steven N, Young LS, Rickinson AB. EpsteinBarr virus latency in blood mononuclear cells: analysis of viral gene transcription during primary infection and in the carrier state. $\mathcal{F}$ Virol 1994;68:7374-85.

42 Jiwa NM, Oudejans JJ, Dukers DF, Vos W, Horstman A, van der Valk $\mathrm{P}$, et al. Immunohistochemical demonstration of different latent membrane protein-1 epitopes of EpsteinBarr virus in lymphoproliferative diseases. $f$ Clin Patho 1995;48:438-42.

43 Khan G, Naase MA. Down-regulation of Epstein-Barr viru nuclear antigen 1 in Reed-Sternberg cells of Hodgkin's disease. $\mathcal{F}$ Clin Pathol 1995;48:845-8.

44 Kaplan LD, Shiramizu B, Herndier B, Hahn J, Meeker TC $\mathrm{Ng} \mathrm{V}$, et al. Influence of molecular characteristics on clinical outcome in human immunodeficiency virus-associated non-Hodgkin's lymphoma: identification of a subgroup with favorable clinical outcome. Blood 1995;85:1727-35. 